\title{
Prevalence and factors associated with excess weight in adolescents in a low- income neighborhood - Northeast, Brazil
}

Lizelda Maria de Araújo Barbosa 1

iD https://orcid.org/0000-0002-4683-4524

Ilma Kruze Grande de Arruda 2

D https://orcid.org/0000-0002-7142-1967

Raquel Canuto 3

https://orcid.org/0000-0002-4042-1913

Pedro Israel Cabral de Lira 4

iD https://orcid.org/0000-0002-1534-1620
Jailma Santos Monteiro 5

(iD https://orcid.org/0000-0002-4995-6172

Déborah Lemos Freitas 6

iD https://orcid.org/0000-0002-6068-8623

Weslla Karla Albuquerque Silva de Paula 7

iD https://orcid.org/0000-0002-0237-2663

Malaquias Batista Filho 8

(iD) https://orcid.org/0000-0002-1490-0590

1,2,4,5 Programa de Pós-Graduação em Nutrição. Departamento de Nutrição. Centro de Ciências da Saúde. Universidade Federal de Pernambuco. Av. Prof. Moraes Rego, nº 1235 - Cidade Universitária, Recife, PE, 50670-901. E-mail: lizelda.araujo@yahoo.com.br

3 Departamento de Nutrição. Faculdade de Medicina. Universidade Federal do Rio Grande do Sul. Porto Alegre, RS, Brasil.

7 Departamento de Enfermagem. Área de Enfermagem em Saúde Coletiva. Centro de Ciências da Saúde. Universidade Federal de Pernambuco. Recife, PE, Brasil.

6,8 Instituto de Medicina Integral Professor Fernando Figueira. Recife, PE, Brasil.

\begin{abstract}
Objectives: to study the prevalence of excess weight and associated factors among adolescents from a low-income neighborhood located in the city of Recife, Pernambuco.

Methods: cross-sectional study, in which behavioral, socioeconomic and demographic information was collected from June to December 2014. Excess weight was calculated based on body mass index for age and the cut-off points, by the World Health Organization (2007). To analyze associations between predictor variables and the outcome, multivariate data analysis was performed following the Poisson Regression (Prevalence Ratio - PR) with their respective $95 \%$ confidence intervals $(95 \%$ CI).

Results: twenty-five adolescents participated in the study, with a prevalence of $36.4 \%$ of excess weight: $20.4 \%$ overweight $(95 \% C I=15.1-25.7)$ and $16.0 \%$ obesity $(95 \% C I=11.2$ 20.8), predominantly in female gender (42.5\%; $p=0.031)$. The outcome was associated with internet access $(P R=1.20 ; 95 \% C I=1.01-1.43)$, the number of people in the family $(P R=1.12$; $95 \% C I=1.01-1.28)$ and screen time $(P R=1.13 ; 95 \% C I=1.01-1.27)$, but only in male gender.

Conclusions: the prevalence found was higher than that of other national researches, especially for the female gender. In the male gender, not having internet access, a lesser number of family members and a longer screen time proved to be factors associated with being excess weight.
\end{abstract}

Key words Adolescent, Poverty, Overweight, Obesity, Prevalence 


\section{Introduction}

The nutritional and epidemiologic transition observed in the past decades, corresponded to the passage of the predominance of infectious/nutritional diseases into a new, conceptually opposite situation, that is, the wide prevalence of noncommunicable diseases (NCDs), which has been growing across the world. ${ }^{1}$ In Brazil, the phenomenon was constituted as a characteristic model of morbimortality, in which infectious/nutritional diseases in quick decline and NCDs in a much more intense expansion rate coexist. ${ }^{2}$

As a result of these transformations, the combined prevalence of overweight/obesity (excess weight) is becoming evident in all economic classes, 3 especially among adolescents. 4 In this age group, excess weight may result from the influence of various factors, among which, biological, behavioral, psychological, and socioeconomic factors. Body changes in this period, 5 as well as concerns on the body image, which includes how adolescents perceive their own body, 6 make adolescence a critical period for the development of nutritional disorders. In this stage, a sedentary lifestyle itself is an independent risk factor for the development of NCDs. 7 From the socioeconomic perspective, obesity is more frequent among low-income individuals with low educational attainment and less privileged occupational status, either in developed or developing countries. 8,9

Therefore, identifying excess weight in poor areas, as well as psychological, behavioral, and economic aspects associated with the problem, might help to understand its effects in adolescence and in plans for future interventions in the collective health field. Regarding this context, this research's aim was to determine the prevalence of excess weight and associated factors among adolescents from a low-income neighborhood located in the city of Recife, Pernambuco, Northeastern Brazil.

\section{Methods}

The research consisted in a cross-sectional study, whose participants derive from the research entitled "Saúde, nutrição e serviços assistenciais numa população favelada do Recife: um estudo baseline", developed in Coelhos Community, a subnormal urban agglomeration ${ }^{10}$ situated in a poor area in the suburbs of Recife, Pernambuco. This censuspurposed survey comprehended 4,739 individuals out of nearly 7,400 inhabitants. The research was approved by the Committee for Ethics in Research of The Professor Fernando Figueira Integral Medicine Institute, protocol number 3201-12, CAAE n. 07246912.6.0000.5201, following the requirements in the National Health Council's Resolution CNS 466/12.

The sample calculation for this study considered as a reference a universe of 1,157 adolescents, registered in both units of the Family Health Strategy (FHS), which assist the families from the community, according to the Primary Care Information System of the Municipal Health Secretariat of Recife, PE, in 2013. For the calculation, the StatCalc-Epi Info version 6.04 was used, considering a prevalence of $16.2 \%$ of excess weight for the age group of 10-19 years in the Metropolitan Region of Recife, PE, in 2006.11 Because of the demographic and nutritional transition which occurred between 2006 and 2014, a 20\% increase was estimated, resulting in an adjusted prevalence of approximately $19 \%$. An error of \pm 5 percentage points and a confidence level of $95 \%$ were considered, which numbers a minimum initial sample of 224 individuals, having all participants been randomly chosen, considering the whole amount of individuals.

Since this study aimed to analyze the variables associated with excess weight, calculations were made to estimate the differences in the set of independent variables. In order to do so, a prevalence ratio of 2.5 was estimated, considering the ratio $1: 1$ (112:112) for a prevalence of $10 \%$ of not exposed and $25 \%$ of exposed, to a confidence level of $95 \%$ (1-alpha) and power of study of $80 \%$ (1-beta).

Data collection occurred between June and December 2014. First, the FHS were visited to present the research to Community Health Workers (CHW). Second, all homes where there were adolescents in the families were visited by the previously trained research team, followed by the CHW from the FHS. If there were more than one adolescent in the family, data of at least one adolescent were collected. All interviews were performed in the interviewees' homes, except for anthropometric data collection, which occurs in a health unit on a previously-scheduled day. The adolescents were informed of the research aim, as well as the adopted parameters. Adolescents of both genders were included, aged between 10-19 years, residents in the community. The ones who had cognitive difficulties to answer the questionnaires, functional limitations to perform the anthropometric assessment, or were pregnant were excluded. Data were only collected after authorization by the Committee for Ethics and signature of the Free and Informed Consent.

The independent variables were collected 
through the application of structured questionnaires, previously tested and codified, applied to the adolescents and their guardians, which were arranged as: demographic (age and gender), socioeconomic (socioeconomic status, internet access, number of rooms, number of family members, and occupational status), house features (type of construction and floor), behavioral (use of video game/cell phone, computer, television, level of physical activity, screen time along the week and weekend), and lastly, psychological variables (personal satisfaction and self-perception of weight). These variables were subjectively assessed through the following questions: "Do you consider yourself happy?" and "How do you consider yourself regarding your weight?".

For the socioeconomic classification, we used the tool of the Brazilian Association of Research Enterprises (ABEP - Portuguese acronym), which includes ownership of household goods and the head of the family's educational attainment level.12 Following ABEP's classification, the adolescents were separated into the following economic categories, according to the gross average household monthly income in reais (Brazilian currency): B1, $\mathrm{B} 2$, and $\mathrm{C} 1$ ( $\mathrm{R} \$ 1,865$ to $\mathrm{R} \$ 6,006)$; $\mathrm{C} 2$ ( $\mathrm{R} \$ 1,277$ to $\mathrm{R} \$ 1,865)$; D and $\mathrm{E}(<\mathrm{R} \$ 1,277)$. Since the study was performed in a low-income community, no individual belonged to class $\mathrm{A}(>\mathrm{R} \$ 6,006)$.

The tool used to measure the level of physical activity was the International Physical Activity Questionnaire (IPAQ), in its short form. 13 To calculate the screen time, we collected time in hours and minutes that the adolescent spent on the video game or cell phone, computer and television on weekdays and weekends. The calculation of time was converted into hours separately for weekdays and weekends and was analyzed as two independent variables. Those whose screen time was longer than two hours per day were classified as "exposed" to excessive screen time. ${ }^{14}$ The variable of self-perception of weight was subjectively assessed by the adolescent through the question: "How do you consider yourself regarding your weight?", with three possible answers: "skinny", "average", or "fat".

The measurements of weight and height were conducted twice, obtained with a digital scale by SECA $^{\circledR} 876$, with capacity of up to $250 \mathrm{~kg}$ and scale of 100 grams, and a mobile stadiometer (Altura exata Ltda) with $1 \mathrm{~mm}$ precision, respectively. To evaluate the nutritional status, the criteria of the World Health Organization (WHO) were adopted through the evaluation of Body Mass Index for age (BMI-for-age) according to gender, for children and adolescents aged 5-19 years. 15

For the classification of the anthropometric indexes, we considered the following cut-off scores: low weight $=<-2$ scores-z; eutrophy $=\geq-2$ scores- $z$ to $<+1$ score-z; overweight $=\geq+1$ score- $z$ and $<+2$ scores-z; and obesity $=\geq+2$ scores-z. For analysis purposes, the nutritional status was categorized as follows: without excess weight (low weight and eutrophy) and with excess weight (overweight and obesity), which is the outcome variable.

Data were entered into the program Epi Info version 3.5.4., designed for Windows. The analyses were carried out with the softwares Statistical Package for the Social Sciences version 1316 and Stata version 1417. For the descriptive analysis, Pearson's chi-squared statistical tests were used for nominal variables, chi-squared test for trend for ordinal variables, and Fisher exact test for variables whose frequency was lower than five. Poisson regression was used to calculate the prevalence ratios and their respective confidence intervals of $95 \%$ for univariate and multivariate. For the latter, Poisson regression was applied through gender-stratified evaluation, besides the total number of adolescents. The variables which showed significance level $p<0.20$ in the univariate analysis were included in the multivariate analysis, which followed the analysis model: on the first level, demographic and socioeconomic variables; on the second level, the variables from the first level which presented $p<0.20$ and the psychological and behavioral variables, controlled by variables on the first level. The considered statistical significance value was $p \leq 0.05$.

\section{Results}

A number of 1,446 residences were visited in the community. There were exactly 1,157 adolescents registered in both ESFs, among which, 958 answered questionnaires of demographic data and 342 answered questionnaires of psychological and behavioral data. As the anthropometry occurred on a different day at the health unit, it had low engagement and hence, a number of only 225 adolescents were present, representing the study's final sample, which corresponds to $19.4 \%$ of the total population. In order to verify that the socioeconomic condition of the excluded individuals in the study $(\mathrm{n}=733)$ did not differ from the included ones' condition $(n=225)$, both were compared regarding occupational status. No statistically significant difference was found $(p=0.945)$.

From the 225 adolescents participating in the study, 98 (43.6\%) were male and 127 (56.4\%) 
female, with an average age of 14.74 years $(\mathrm{SD}=2.86)$. In the total population of adolescents, the authors found excess weight prevalence of $63.4 \%$, out of which, $20.4 \%(\mathrm{CI} 95 \%=15.1-25.7)$ were overweight and $16.0 \%(\mathrm{CI} 95 \%=11.2-20.8)$ were obese. The sample was predominantly constituted of adolescents in the socioeconomic class C2 $(41.3 \%$; CI95\% $=35.3-48.3)$, who were not working $(65.6 \%$; $\mathrm{CI} 95 \%=59.2-71.9)$ and had internet access $(78.4 \%$; CI95\% $\%$ 72.9-83.9). Furthermore, the authors observed that $61.8 \%$ lived in homes with more than four rooms $(\mathrm{CI} 95 \%=55.4-68.2), 96.8 \%$ considered themselves happy $(\mathrm{CI} 95 \%=94.4-99.1)$ and $50.9 \%$ considered themselves in average weight for their age $(\mathrm{CI} 95 \%=44.2$ - 57.6). Regarding the total number of family members, there was a homogeneous distribution: $52.7 \%$ (CI95\% $=46.1-59.3)$ belonged to families with less than four people and $47.3 \%(\mathrm{CI} 95 \%=40.7-53.9)$ to families with more than four. The losses by lack of information occurred in the variable number of family members (three losses). (Not-shown data).

Table 1 shows the gender-stratified descriptive analysis. It can be observed that the variables number of rooms, usage of video game/cell phone, television, level of physical activity, type of home construction and floor are statistically different when compared to gender. Regarding the male adolescents, most of them lived in homes with more than four rooms $(73.5 \%, p=0.002)$, used video game/cell phone $(73.5 \%, p=0.001)$ and lived in masonry houses $(94.9 \%, p=0.018)$ with ceramic floors $(66.3 \%, p=0.023)$. On the other hand, the girls watched more television $(98.4 \%, p=0.009)$, were more irregularly active $(33.9 \%, p<0.001)$ and lived in cardboard, canvas, or wood houses $(15 \%$, $p=0.018$ ) with wood floor $(48.8 \%, p=0.023)$. (Table 1)

Table 2 shows associations of the excess weight with the independent variables assessed in the univariate analysis. It shows higher excess weight prevalences among female adolescents $(42.5 \%$, $p=0.029)$, those who used computer $(49.3 \%$, $p=0.007)$, those who were irregularly active $(49.2 \%$, $p=0.016$ ) and those who perceive themselves as "fat" (78.2\%, $p<0.001)$. (Table 2)

By including variables in the multivariate model, self-perception of weight was the only which kept the association with the excess weight occurrence in both genders in an independent way. From the total population, the adolescents who considered themselves "fat" had an excess weight prevalence of $61 \%$ higher than the ones who considered themselves "skinny", regardless of the other variables analyzed.
As the gender-stratified multivariate analysis was carried out, we observed that among male adolescents, not having internet access, having less than four family members, and spending more than two hours per day on screen on the weekend were factors that increased the probability of excess weight occurence in $20 \%, 12 \%$, and $13 \%$, respectively, even after the adjustments in the association of the outcome with the other exploratory variables. (Table 3)

\section{Discussion}

The results in this study corroborate the universalization of the epidemiologic transition, scientifically known in developed countries to be an event that has begun around 50 years ago, 18,19 and in Brazil and Latin America, in the past four decades, 2 also generally in the different socioeconomic status in the urban spaces. In general, subnormal urban agglomeration is home to families who live under environmental and socioeconomic conditions that are very precarious, and should present, as a probabilistic scenario, fundamentally unfavorable situations, specifically including the prevalence of nutritional aggravations. 10 However, prevalence of excess weight in the total population $(36,4 \%)$ was higher than the national average, 4 revealing the epidemic levels of the problem, which corresponds to situations particular to developed countries, such as the United States, Canada and the United Kingdom. 18,19 This was an important finding that should be deeply analysed as a generic matter of the transition process and as a particularity of the urban populations who live in places of great poverty.

When compared to other cities in Northeastern Brazil, the prevalence found was higher than what was identified in the metropolitan area of Recife, PE, ${ }^{11}(16.2 \%)$ and other cities, such as Salvador, BA, 20 (15.7\%), Maceió, AL, 21 (13.8\%), Fortaleza, CE, 22 (24\%), João Pessoa, PB, 23 (27.2\%) and Imperatriz, MA, 24 (16.9\%). Nevertheless, national studies on prevalence of excess weight in lowsocioeconomic-status adolescents are still limited, which hinders a more conclusive analysis of aggravation in those populations. ${ }^{3}$

The etiology of excess weight has been shown as complex and multicausal. ${ }^{3}$ In this study, the possible sociodemographic, behavioral and psychological determinations. Excess weight was more prevalent in adolescents, similarly to previous studies found.11,20,23 Although data on sexual maturation have not been collected, the literature states that the highest prevalence rates for excess weight in girls 
Distribution of demographic, socioeconomic, behavioral, psychological and nutritional status of adolescents according to gender. Coelhos Community - Recife, PE, 2014.

\begin{tabular}{|c|c|c|c|c|c|}
\hline \multirow{2}{*}{ Variables } & \multicolumn{2}{|c|}{ Male } & \multicolumn{2}{|c|}{ Female } & \multirow{2}{*}{$p^{*}$} \\
\hline & $\mathrm{n}$ & $\%$ & $\mathrm{n}$ & $\%$ & \\
\hline Age range & & & & & 0.318 \\
\hline 10 to 14 years & 49 & 50.0 & 55 & 43.3 & \\
\hline 15 to 19 years & 49 & 50.0 & 72 & 56.7 & \\
\hline Socioeconomic Class & & & & & 0.934 \\
\hline $\mathrm{B} 1, \mathrm{~B} 2, \mathrm{C} 1$ & 25 & 25.5 & 33 & 26.0 & \\
\hline $\mathrm{C} 2$ & 41 & 41.8 & 53 & 41.7 & \\
\hline$D, E$ & 32 & 32.7 & 41 & 32.3 & \\
\hline Internet access & & & & & 0.943 \\
\hline Yes & 76 & 77.6 & 99 & 78.0 & \\
\hline No & 22 & 22.4 & 28 & 22.0 & \\
\hline Number of rooms & & & & & $0.002^{a}$ \\
\hline$\leq 4$ & 26 & 26.5 & 60 & 47.2 & \\
\hline$>4$ & 72 & 73.5 & 67 & 52.8 & \\
\hline Number of family members & & & & & 0.703 \\
\hline$\leq 4$ & 52 & 54.2 & 65 & 51.6 & \\
\hline$>4$ & 44 & 45.8 & 61 & 48.4 & \\
\hline Nutritional status & & & & & $0.031 c$ \\
\hline Underweight & 6 & 6.1 & 2 & 1.6 & \\
\hline Eutrophy & 64 & 65.3 & 71 & 55.9 & \\
\hline Overweight & 15 & 15.3 & 31 & 24.4 & \\
\hline Obesity & 13 & 13.3 & 23 & 18.1 & \\
\hline Type of house construction & & & & & $0.018 \mathrm{a}$ \\
\hline Masonry / brick + mud & 93 & 94.9 & 108 & 85.0 & \\
\hline Cardboard / Canvas / Wood & 5 & 5.1 & 19 & 15.0 & \\
\hline House's floor type & & & & & $0.023^{a}$ \\
\hline Ceramics & 65 & 66.3 & 65 & 51.2 & \\
\hline Wood / cement / other & 33 & 33.7 & 62 & 48.8 & \\
\hline Video game or cell phone usage & & & & & $0.001 \mathrm{a}$ \\
\hline Yes & 72 & 73.5 & 65 & 51.2 & \\
\hline No & 26 & 26.5 & 62 & 48.8 & \\
\hline Computer usage & & & & & 0.078 \\
\hline Yes & 74 & 75.5 & 82 & 64.6 & \\
\hline No & 24 & 24.5 & 45 & 35.4 & \\
\hline Television usage & & & & & $0.009 a$ \\
\hline Yes & 89 & 90.8 & 125 & 98.4 & \\
\hline No & 9 & 9.2 & $2 c$ & 1.6 & \\
\hline Physical activity level & & & & & $<0.001 \mathrm{~b}$ \\
\hline Irregularly active & 18 & 18.4 & 43 & 33.9 & \\
\hline Active & 47 & 48.0 & 70 & 55.1 & \\
\hline Very active & 33 & 33.7 & 14 & 11.0 & \\
\hline Screen time on weekdays & & & & & 0.379 \\
\hline$<2$ hours / day & 12 & 12.2 & 11 & 8.7 & \\
\hline$\geq 2$ hours / day & 86 & 87.8 & 116 & 91.3 & \\
\hline Screen time on weekends & & & & & 0.158 \\
\hline$<2$ hours / day & 15 & 15.3 & 29 & 22.8 & \\
\hline$\geq 2$ hours / day & 83 & 84.7 & 98 & 77.2 & \\
\hline Self-perception of weight & & & & & 0.083 \\
\hline "Skinny" & 30 & 30.6 & 27 & 21.3 & \\
\hline "Average" & 48 & 49.0 & 65 & 51.2 & \\
\hline "Fat" & 20 & 20.4 & 35 & 27.6 & \\
\hline
\end{tabular}

a $p<0.05$ for Pearson's chi-squared test, b $p<0.05$ for chi-squared test for trend, $c p<0.05$ Fisher exact test. 
Table 2

Excess weight in adolescents according to demographic, socioeconomic, behavioral and psychological variables. Coelhos Community - Recife, PE, 2014.

\begin{tabular}{|c|c|c|c|c|c|c|c|}
\hline \multirow{2}{*}{ Variables } & \multicolumn{2}{|c|}{ Total } & \multicolumn{4}{|c|}{ With excess weight * } & \multirow{2}{*}{$p$} \\
\hline & $\mathrm{n}$ & $\%$ & $\mathrm{n}$ & $\%$ & Gross PRa & $\mathrm{Cl} 95 \% \mathrm{~b}$ & \\
\hline \multicolumn{8}{|l|}{ Gender } \\
\hline Male & 98 & 43.6 & 28 & 28.6 & 1 & & \\
\hline Female & 127 & 56.4 & 54 & 42.5 & 1.11 & $1.01-1.21$ & 0.029 \\
\hline \multicolumn{8}{|l|}{ Age range } \\
\hline 15 to 19 years & 121 & 53.8 & 43 & 35.5 & 1 & & \\
\hline 10 to 14 years & 104 & 46.2 & 39 & 37.5 & 1.01 & $0.91-1.10$ & 0.978 \\
\hline \multicolumn{8}{|l|}{ Socioeconomic Class } \\
\hline$D, E$ & 73 & 32.4 & 25 & 34.2 & 1 & & \\
\hline $\mathrm{C} 2$ & 94 & 41.8 & 34 & 36.2 & 1.01 & $0.91-1.13$ & 0.529 \\
\hline $\mathrm{B} 1, \mathrm{~B} 2, \mathrm{C} 1$ & 59 & 25.8 & 23 & 39.7 & 1.04 & $0.92-1.17$ & \\
\hline \multicolumn{8}{|l|}{ Internet access } \\
\hline Yes & 175 & 77.8 & 59 & 33.7 & 1 & & \\
\hline No & 50 & 22.2 & 23 & 46.0 & 1.09 & $0.98-1.22$ & 0.112 \\
\hline \multicolumn{8}{|l|}{ Number of rooms } \\
\hline$>4$ & 139 & 61.8 & 46 & 33.1 & 1 & & \\
\hline$\leq 4$ & 86 & 38.2 & 36 & 41.9 & 1.06 & $0.97-1.17$ & 0.185 \\
\hline \multicolumn{8}{|l|}{ Number of family members } \\
\hline$>4$ & 108 & 47.3 & 33 & 31.4 & 1 & & \\
\hline$\leq 4$ & 117 & 52.7 & 48 & 41.0 & 1.07 & $0.98-1.18$ & 0.136 \\
\hline \multicolumn{8}{|l|}{ Type of house construction } \\
\hline Masonry / brick + mud & 201 & 89.3 & 71 & 35.3 & 1 & & \\
\hline Cardboard / Canvas / Wood & 24 & 10.7 & 11 & 45.8 & 1.08 & $0.93-1.24$ & 0.314 \\
\hline \multicolumn{8}{|l|}{ House's floor type } \\
\hline Ceramics & 130 & 57.8 & 45 & 34.6 & 1 & & \\
\hline Wood / cement / other & 95 & 42.2 & 37 & 38.9 & 1.03 & $0.94-1.13$ & 0.506 \\
\hline \multicolumn{8}{|l|}{ Video game or cell phone usage } \\
\hline Yes & 137 & 60.9 & 47 & 34.3 & 1 & & \\
\hline No & 88 & 39.1 & 35 & 39.8 & 1.04 & $0.95-1.14$ & 0.407 \\
\hline \multicolumn{8}{|l|}{ Computer usage } \\
\hline Yes & 156 & 69.3 & 48 & 30.8 & 1 & & \\
\hline No & 69 & 30.7 & 34 & 49.3 & 1.14 & $1.04-1.26$ & 0.007 \\
\hline \multicolumn{8}{|l|}{ Television usage } \\
\hline Yes & 11 & 4.9 & 3 & 27.3 & 1 & & \\
\hline No & 214 & 95.1 & 79 & 36.9 & 1.07 & $0.87-1.33$ & 0.501 \\
\hline \multicolumn{8}{|l|}{ Physical activity level } \\
\hline Very Active & 47 & 20.9 & 13 & 27.7 & 1 & & \\
\hline Active & 117 & 52.0 & 39 & 33.3 & 1.04 & $0.93-1.18$ & 0.016 \\
\hline Irregularly active & 61 & 27.1 & 30 & 49.2 & 1.17 & $1.02-1.33$ & \\
\hline \multicolumn{8}{|l|}{ Screen time on weekdays } \\
\hline$<2$ hours / day & 23 & 10.2 & 5 & 21.7 & 1 & & \\
\hline$\geq 2$ hours / day & 202 & 89.8 & 77 & 38.1 & 1.13 & $0.98-1.31$ & 0.092 \\
\hline \multicolumn{8}{|l|}{ Screen time on weekends } \\
\hline$<2$ hours / day & 44 & 19.6 & 16 & 36.4 & 1 & & \\
\hline$\geq 2$ hours / day & 181 & 80.4 & 66 & 36.5 & 0.98 & $0.87-1.10$ & 0.738 \\
\hline \multicolumn{8}{|l|}{ Self-perception of weight } \\
\hline "Skinny" & 57 & 25.3 & 4 & 7.0 & 1 & & \\
\hline "Average" & 113 & 50.2 & 35 & 31.0 & 1.22 & $1.11-1.34$ & $<0.001$ \\
\hline "Fat" & 55 & 24.4 & 43 & 78.2 & 1.65 & $1.52-1.83$ & \\
\hline
\end{tabular}

${ }^{*}$ Excess weight $=$ overweight + obesity, a gross PR $=$ gross Prevalence Ratio, b Cl95\% $=95 \%$ Confidence Interval. 
Table 3

Gross and adjusted prevalence ratio (PR) to excess weight in adolescents. Coelhos Community - Recife, PE, 2014

\begin{tabular}{|c|c|c|c|c|c|c|c|c|c|}
\hline \multirow{2}{*}{ Variables } & \multicolumn{3}{|c|}{ Total } & \multicolumn{3}{|c|}{ Masculino } & \multicolumn{3}{|c|}{ Feminino } \\
\hline & Gross RP (Cl95\%)a & Adjusted PR (Cl95\%) & a $p$ & Gross RP (Cl95\%)a & Adjusted PR (C195\%) & ) a $p$ & Gross RP (C195\%)a & Adjusted PR (CI95\%) & b) a $p$ \\
\hline \multicolumn{10}{|l|}{ Level $1 \mathrm{~b}$} \\
\hline \multicolumn{10}{|l|}{ Gender } \\
\hline Male & 1 & 1 & & - & - & - & - & - & - \\
\hline Female & $1.11(1.01-1.21)$ & $1.09(1.00-1.20)$ & 0.052 & - & - & - & - & - & - \\
\hline \multicolumn{10}{|l|}{ Internet access } \\
\hline Yes & 1 & 1 & & 1 & 1 & & - & - & - \\
\hline No & $1.09(0.98-1.22)$ & $1.09(0.97-1.22)$ & 0.126 & $1.17(0.99-1.38)$ & $1.20(1.01-1.43)$ & 0.037 & - & - & - \\
\hline \multicolumn{10}{|l|}{ Number of rooms } \\
\hline$>4$ & 1 & 1 & & - & - & - & 1 & 1 & \\
\hline$\leq 4$ & $1.06(0.97-1.17)$ & $1.02(0.93-1.12)$ & 0.617 & - & - & - & $1.10(0.98-1.24)$ & $1.10(0.98-1.24)$ & 0.105 \\
\hline \multicolumn{10}{|c|}{ Number of family members } \\
\hline$>4$ & 1 & 1 & & 1 & 1 & & - & - & - \\
\hline$\leq 4$ & $1.07(0.98-1.18)$ & $1.07(0.98-1.17)$ & 0.142 & $1.13(0.99-1.30)$ & $1.12(1.01-1.28)$ & 0.049 & - & - & - \\
\hline \multicolumn{10}{|l|}{ Level $2 c$} \\
\hline \multicolumn{10}{|l|}{ Computer usage } \\
\hline Yes & 1 & 1 & & 1 & 1 & & 1 & 1 & \\
\hline No & $1.14(1.04-1.26)$ & $1.07(0.97-1.17)$ & 0.157 & $1.13(0.97-1.34)$ & $1.09(0.94-1.25)$ & 0.244 & $1.12(0.99-1.27)$ & $1.05(0.94-1.18)$ & 0.349 \\
\hline \multicolumn{10}{|l|}{ Physical activity level } \\
\hline Very Active & 1 & 1 & & 1 & 1 & & - & - & - \\
\hline Active & $1.04(0.93-1.18)$ & $1.02(0.92-1.13)$ & 0.229 & $0.96(0.82-1.11)$ & $0.97(0.84-1.12)$ & 0.207 & - & - & - \\
\hline Irregularly active & $1.17(1.02-1.33)$ & $1.06(0.94-1.19)$ & & $1.30(1.08-1.56)$ & $1.13(0.95-1.34)$ & & - & - & - \\
\hline \multicolumn{10}{|c|}{ Screen time on weekdays } \\
\hline$<2$ hours / day & 1 & 1 & & - & - & - & - & - & - \\
\hline$\geq 2$ hours / day & $1.13(0.98-1.31)$ & $1.12(0.98-1.27)$ & 0.086 & - & - & - & - & - & - \\
\hline \multicolumn{10}{|c|}{ Screen time on weekends } \\
\hline$<2$ hours / day & - & - & - & 1 & 1 & & 1 & 1 & \\
\hline$\geq 2$ hours / day & - & - & - & $1.17(0.99-1.38)$ & $1.13(1.01-1.27)$ & 0.048 & $0.91(0.79-1.04)$ & $0.92(0.81-1.03)$ & 0.165 \\
\hline \multicolumn{10}{|c|}{ Self-perception of weight } \\
\hline "Skinny" & 1 & 1 & & 1 & 1 & & 1 & 1 & \\
\hline "Average" & $1.22(1.11-1.34)$ & $1.22(1.11-1.34)$ & $<0.001$ & $1.23(1.09-1.38)$ & $1.21(1.07-1.37)$ & $<0.001$ & $1.20(1.05-1.38)$ & $1.18(1.03-1.36)$ & $<0.001$ \\
\hline "Fat" & $1.65(1.52-1.83)$ & $1.61(1.48-1.78)$ & & $1.64(1.44-1.88)$ & $1.50(1.30-1.73)$ & & $1.64(1.45-1.87)$ & $1.60(1.41-1.84)$ & \\
\hline
\end{tabular}

aPrevalence ratio and its respective confidence intervals of $95 \%$, bLevel $1=$ adjusted to the other variables on this level, cLevel $2=$ adjusted by variables on level 1 . 
can be partially explained by the greater vulnerabilty of the female organism to accumulate body fat, which occurs through the sexual hormones in ages near puberty. 5

The lack of association between socioeconomic status and excess weight was a striking finding, since the studied area has expressive economic vulnerability, has high prevalence rates for obesity, and that is indicated in the studies. ${ }^{8,9}$ However, it is worth remarking that the majority of the studied adolescents were in classes $\mathrm{C} 2, \mathrm{D}$ and $\mathrm{E}$, constituting a homogeneous group among the assessed families. In those homogeneous communities with access to essential consumer goods, the traditional indicators for assessing socioeconomic condition have been shown as not much sensitive to detect differences between the groups, while other more recent alternative methods, such as internet access, displayed more association with the socioeconomic condition.

In this investigation, not having internet access was an associated factor to excess weight among male adolescents. A study 25 states that low-income populations are more likely to experience social challenges, including limited internet access and devices with connection to it, which, for that status, makes that variable represent more the socioeconomic status than the behavioral aspect. This way, not having internet access at home would mean having lower financial condition and less equitable access to social opportunities, 25 which would, then, make those teenagers to be more exposed to irregular access to healthcare 25,26 and excess weight. 8 This result is in consonance with Mayen et al. 8 systematic review, from which the authors have concluded that the best socioeconomic condition and the urban area were associated with higher food quality, diversity and healthier dietary patterns, then, constituting a protection factor for the occurence of NCDs, among which is obesity.

Therefore, not having internet access and having less than four people in the family were associated with higher probability of excess weight among male adolescents, which demonstrates that the difference in the prevalence of overweight between genders, besides a biological matter, can be influenced by a socioeconomic difference between genders.

Concerning family size, Ochiai et al. ${ }^{26}$ argue that it can influence the nutritional status of low-income individuals: the more members in the family, the lower the probability of obesity. That occurs due to the existence of financial difficulties to access and share foods among relatives, promoting lower total individual calorie intake and, consequently, no excess weight gain. 27
In this research, we measured the time the teenagers spent on video games or cell phone, computer and television, on weekdays and weekends. These variables together reveal screen time, considered as a marker for sedentary behaviour in children and adolescents. When that time is longer than two hours per day, it is a risk factor for diseases related to obesity. ${ }^{14}$ After the adjustments for the confusion variables, screen time longer than two hours per day on weekends appeared as a factor associated to excess weight in male adolescents. The long time dedicated to sedentary leisure activities is a reality for adolescents and appears in national 28 and also international29 studies. Concern with violence is a social factor that collaborates for teenagers to seek fun inside their homes, making them sedentary. Along with that, the modern environment cooperates for teenagers to opt for watching television instead of doing sports, as they use the computer or cell phone to talk to their friends and play video games instead of engaging in play at school or on the street.28,29

Self-perception of weight was independently associated with the occurrence of excess weight in both genders, similarly to what has been found in Pereira et al. 30 study, suggesting that they were aware of their nutritional status regardless of other behavioral and socioeconomic factors. Although most of the adolescents had an adequate perception, that data deserves caution to be interpreted, as it is a subjective analysis. The literature recommends the use of tools, such as the Figure Rating Scale and questionnaires, because they aim to identify discrepancies between real body and desired body, 6 a methodology that has not been applied to this study.

This research contributes to the existing literature for the following strong points: (a) there are few studies in the national and international literature on prevalence and factors associated to excess weight in low-income adolescents; (b) in face of the lack of studies in poverty areas, establishing the magnitude of the problem from a perspective of primarily preventive interventions in the collective health field is fundamental; (c) the measures were taken by using suitable and reliable techniques performed by previously trained interviewers; (d) the variables were adjusted through multivariate analysis techniques adequate for the research design.

On the other hand, there might be some methodological limitations that should be examined for the interpretation and validity of the results: (a) the absence of information on the sexual maturation stage; (b) some information, such as hours of sedentary activity and physical activity, was mentioned by 
the adolescents themselves and is subjected to memory bias; (c) there might have been reverse causality bias, due to transversality in the study.

The prevalence of excess weight in adolescents from Coelhos community was higher than what was found in previous national studies. In that set of cases, behavioral and socioeconomic factors, and excess weight combined in different ways between genders: the factors that combined with excess weight for the male gender were not having internet access, the smallest number of people in the family and screen time longer than two hours per day on weekends, and for both genders, only self-perception of body weight. The absence of association with the levels of physical activity regardless of the excess weight suggests the need for new studies concerning these variables in low-income communities, since the literature has been displaying those associations.

This investigation proved to be important for contributing with new findings in the national scope, bringing data that can serve as reflection for other similar populations. The identified reality provides means for interventions in Family Health Units which can significantly improve life quality and nutritional status of the individuals in the community, aiming to promote adolescent health. The

\section{References}

1. Afshin A, Forouzanfar M, Reitsma M, Sur P, Estep K, Lee A, Marczak L, Mokdad AH, et al. Health Effects of Overweight and Obesity in 195 Countries over 25 Years. N Engl J Med. 2017; 377 (1): 13-27.

2. Batista Filho M, Rissin A. A transição nutricional no Brasil: tendências regionais e temporais. Cad Saúde Pública. 2003; 19 (Supl.1): S181-S91

3. Niehues JR, Gonzales AI, Lemos RR, Bezerra PP, Haas P. Prevalence of overweight and obesity in children and adolescents from the age range of 2 to 19 years old in Brazil. Int J Pediatr. 2014; (583207): 1-7.

4. Bloch KV, Klein CH, Szklo M, Kuschnir MCC, Abreu G de A, Barufaldi LA, Veiga GV, Schaan B, Silva TLN. ERICA prevalências de hipertensão arterial e obesidade em adolescentes brasileiros. Rev Saúde Pública. 2016; 50 (Supl. 1): $1-13$.

5. Daniels SR, Arnett DK, RH Eckel, SS Gidding, Hayman LL, Kumanyika S, Robinson TN, BJ Scott, St Jeor S , Williams CL. Overweight in children and adolescents: Pathophysiology, consequences, prevention, and treatment. Circulation. 2005; 111 (15): 1999-2012.

6. Garcia DM, Mekitarian Filho E, Gilio AE, Lotufo JPB, Lo DS. Estado nutricional, autopercepção do estado nutricional e experimentação de drogas lícitas em adolescentes. Rev Paul Pediatr. 2015; 33 (3): 332-9. proposed intersectoral actions must ensure food security for the families, the reduction of social inequalities, incentive to change of lifestyle and the adolescents' awareness about their participation in the process of producing their own health. In face of the scarcity of works on low-income communities, it is necessary to carry more studies with those populations.

\section{Authors' contributions}

Barbosa LMA - bibliographic survey, data analysis and interpretation, article writing, approval of the final version to be submitted. Arruda IKG, Lira PIC and Paula WKAS - study design and conception, data analysis and interpretation, critical review of relevant intellectual content, approval of the final version to be submitted. Canuto R - Data analysis and interpretation, critical review of relevant intellectual content, approval of the final version to be submitted. Monteiro JS, Freitas DL and Batista Filho M - study design and conception, data analysis and collection, approval of the final version to be submitted. All authors approved the final version of the manuscript.
7. Vasconcelos F, Seabra A, Katzmarzyk PT, Kraemer-Aguiar LG, Bouskela E, Farinatti P. Physical activity in overweight and obese adolescents : systematic review of the effects on physical fitness components and cardiovascular risk factors. Sports Med. 2014; 44 (8): 1139-52.

8. Mayén A-L, Marques-Vidal P, Paccaud F, Bovet P, Stringhini $\mathrm{S}$. Socioeconomic determinants of dietary patterns in lowand middle-income countries: a systematic review. Am J Clin Nutr. 2014; 100 (6): 1520-31.

9. Popkin BM, Slining MM. New dynamics in global obesity facing low- and middle-income countries. Obes Rev. 2013; 14 (2): 11-20.

10. IBGE (Instituto Brasileiro de Geografia e Estatística). Censo demográfico: Aglomerados subnormais - informações territoriais. Rio de Janeiro: 2010. p. 1-251

11. Leal VS, Lira PIC, Oliveira JS, Menezes RCE, Sequeira LAS, Neto MAA, Andrade SLLS, Batista Filho M. Excesso de peso em crianças e adolescentes no Estado de Pernambuco, Brasil: prevalência e determinantes. Cad Saúde Pública. 2012; 28 (6): 1175-82.

12. ABEP (Associação Brasileira de Empresas de Pesquisa). Dados com base no Levantamento Sócio Econômico 2014 - IBOPE [Internet]. 2014. [acesso em 19 mar 2018]. Disponível em: http://www.abep.org/Servicos/Download. aspx?id=01 
13. Matsudo S, Araújo T, Matsudo V, Andrade D, Andrade E, Oliveira LC, Braggion G. Questionário Internacional de Atividade Física (IPAQ): Estudo de Validade e Reprodutibilidade no Brasil. Rev Bras Ativ Fis Saúde. 2012; 6 (2): 5-18.

14. SBP (Sociedade Brasileira de Pediatria). Obesidade na infância e adolescência - Manual de Orientação. Departamento Científico de Nutrologia. 2 ed. São Paulo: SBP; 2012. p.142.

15. Onis M de, Adelheid W Onyango, Borghi E, Siyam A, Nishidaa C, Siekmanna J. Development of a WHO growth reference for school-aged children and adolescents. Bull World Heal Organ. 2007; 85(9): 660-7.

16.Statistical Package for the Social Sciences. SPSS for Windows 13. Software. Disponível em: https://www.ibm.com/br-pt/products/spss-statistics

17.Stata versão 14. Software. Disponível em: https://www.stata.com/support/faqs/resources/citing-software-documentation-faqs/

18. Conference of european statisticians recommendations for the 2010 censuses of population and housing [Internet] Geneva: United Nations. 2006. [cited 2018 mar 24]. p. 200 Available from: https://www.unece.org/fileadmin/ DAM/stats/publications/CES_2010_Census_Recommendat ions_English.pdf

19. Dick P. The census of Canada: the dwelling classification study. In: Joint Statistical Meetings. Proceedings. Alexandria: United States: ASA ASA; 2002. p. 782-7.

20. Marques CDF, Silva R de CR, Machado MEC, Santana MLP de, Cairo RCA, Pinto EJ , Maciel LOR, Silva LR. The prevalence of overweight and obesity in adolescents in Bahia, Brazil. Nutr Hosp. 2013; 28 (2): 491-6.

21. Mendonça MRT, Silva MAM da, Rivera IR, Moura AA Prevalência de sobrepeso e obesidade em crianças e adolescentes da cidade de Maceió. Rev Assoc Med Bras. 2010; 56 (2): 192-6.

22. Araújo MFM, Almeida LS de, Silva PCV da, Vasconcelos HCA de, Lopes MV de O, Damasceno MMC. Sobrepeso entre adolescentes de escolas particulares de Fortaleza, CE, Brasil. Rev Bras Enferm. 2010; 63 (4): 651-8.
23. Lima RPA, Pereira DC, Luna RCP, Gonçalves MCR, Lima RT, Batista Filho M, Filizola RG, Moraes RM, Asciutti LSR, Costa MJC. BMI, overweight status and obesity adjusted by various factors in all age groups in the population of a city in northeastern Brazil. Int $\mathrm{J}$ Environ Res Public Health. 2015; 12 (4): 4422-38.

24. Nascimento-Ferreira MV, Moraes ACF, Carvalho HB, Moreno LA, Carneiro ALG, Reis VMM, Torres-Leal FL. Prevalence of cardiovascular risk factors, the association with socioeconomic variables in adolescents from lowincome region. Nutr Hosp. 2015; 31 (1): 217-24.

25. Katz VS, Gonzalez C, Clark K. Digital Inequality and Developmental Trajectories of Low-income, Immigrant, and Minority Children. Pediatrics. 2017; 140 (Suppl. 2): S132-S8.

26. Ochiai H, Shirasawa T, Ohtsu T, Nishimura R, Morimoto A, Obuchi R, Hoshino H, Tajima N, Kokaze A. Number of siblings, birth order, and childhood overweight: a population-based cross-sectional study in Japan. BMC Public Health. 2012; 12 (766): 1-7.

27. Mosli RH, Miller AL, Peterson KE, Kaciroti N, Rosenblum $\mathrm{K}$, Baylin A, Lumeng JC. Birth order and sibship composition as predictors of overweight or obesity among lowincome 4- to 8-year-old children. Pediatr Obes. 2017; 11 (1): $40-6$.

28. Tassitano RM, Barros MVG, Tenório MCM, Bezerra J, Hallal PC. Prevalência e fatores associados ao sobrepeso e à obesidade em adolescentes, estudantes de escolas de Ensino Médio de Pernambuco, Brasil. Cad de Saúde Pública. 2009; 25 (12): 2639-52.

29. Moreno LA, Gottrand F, Huybrechts I, Ruiz JR, GonzálezGross M, DeHenauw S; HELENA Study Group. Nutrition and Lifestyle in European Adolescents: the HELENA (Healthy Liftestyle in Europe by Nutrition in Adolescence) Study. Adv Nutr. 2014; 5 (5): 615S-23S.

30. Pereira FN, Oliveira JR de, Zöllner CC, Gambardella AMD. Percepção do peso corporal e fatores associados em estudantes do Espírito Santo, Brasil. J Hum Growth Dev. 2013; 23 (3): 296-302.

Received on August 10, 2018

Final version presented on May 07, 2019

Approved on June 21, 2019 